\title{
The Use of Authentic Materials in Teaching Grammar for EFL Students (Teachers' Perspective)
}

\author{
Sri Agriyanti Mestari \\ Fahria Malabar \\ Universitas Negeri Gorontalo
}

\begin{abstract}
The goal of this paper is to analyze the use of authentic material in teaching grammar for EFL students. Kilickaya (2004) define authentic materials as exposure to real language and use in its own community. Peacock (1997) has another definition of authentic materials which is"the materials that have been produced to fulfill some social purposes in the language community". Authentic materials are assume as the important tools for teachers in class in order to make his/her teaching effective in transmitting the necessary knowledge to all students. This presentation will discuss the effects of using authentic material in teaching grammar from teachers' perspective and offer how authentic material can be used in grammar EFL class.
\end{abstract}

Keywords: Authentic materials, teaching grammar, teachers' perspective

\section{Introduction}

The ability to use grammar accurately, meaningfully and appropriately is needed for English learner to communicate both in oral and written way. What is to write and speak must be based on correct grammar, so that the message conveyed can be understood. In teaching grammar, mostly use textbook or published material. If these materials are used continuously, it can make learners less motivated in studying the language. To deal with this problem a teacher can provide a supplementary material to support the textbook. The supplementary materials are generally known as authentic materials. Morley and Guariento (2001) claim that the purpose of using authentic materials is to prepare students for their social lives. In other words, the authentic materials are used in order to close the language gap between classroom knowledge and real life. Similarly, Spelleri (2002) supports this analysis, she thinks that the language used in text books are only valid in a classroom environment whereas the requirement of real life English is different and this difference has not yet been closed by the use of text books because learners have to deal with the language of brochures, office work, application forms and others cultural product. In this case the role of the teacher is crucial; it is the teacher's responsibility to filter materials through selection of the learning objectives. It is the teacher's responsibility to identify the items and their adaptability as well.

Authentic material according to Kilickaya (2004) is defined as exposure to real language and use in its own community. Peacock (1997) has another definition of authentic materials which is "the materials that 
have been produced to fulfill some social purposes in the language community". In addition Lundahl as cited in Ling and Daskalos (2005) states that "Authentic material" refers to e.g. books and articles where language and structure are not simplified in any way, it should be introduced in the classroom. For teaching purposes this refers to English books, novels or articles that have been written by an English speaking author to a native audience or speaker; in these cases the language used has not been altered. According to Nunan (1999, p.80)

The term "authentic text" covers language samples drawn from a wide variety of contexts, including TV and radio broadcasts, conversations, discussions and meetings of all kinds, talks, and announcements [as well as] magazines, stories, printed material and instructions, hotel brochures and airport notices, bank instructions, and a wide range of written messages.

The idea of using authentic materials in teaching English has come long time ago since the introduction of communicative approach in 1970's. It is known that authentic materials have advantages for teaching English to EFL students. In teaching grammar, authentic materials help the students to recognize the samples of English used by its native speakers in all kinds of language use. In addition, authentic materials make the students be more communicative in classroom activities. According to Phillips and Shettlesworth (1978); Clarke (1989); Peacock (1997) as cited in Richard (2001), authentic materials have some advantages. Firstly, they have a positive effect on students' motivation. Secondly, they provide authentic cultural information about the target culture. Thirdly, they provide exposure to real language. Fourthly, they relate more closely to students' needs. And finally, they support a more creative approach to teaching. Otte and Thanajaro as cited in Al-Rashid and Al-Azri (2014) noticed that learners' self-satisfaction and motivation showed improvement after employing authentic texts in the classroom. Authentic materials help motivate learners learn the language by making them feel that they are learning the 'real' language.

On the other hand, there are some significant disadvantages of using authentic materials in comparison with textbooks. Martinez as cited in Berardo (2006) believes that authentic materials may be too culturally biased. Good knowledge of cultural background is needed to understand the text. Another weakness is many structures are mixed in such materials, causing lower levels students difficult to decode the texts. Guariento and Morley (2001) remind us that the use of authentic materials makes especially lower level students confused and demotivated by the complexity of language and performance conditions unless the simplest authentic texts are carefully selected by the teachers. Ruddock as cited in Saraph (2011) gives an example about when to use authentic texts in teaching the grammatical structure of Japanese. Ruddock says authentic texts are only use when students reach intermediate level in the teaching of grammar. Because it is considered that authentic texts are 
difficult for beginners. Additionally, Richard (2001) said that using authentic materials is a burden for teachers. It because teachers have to spend a substantial amount of time to set the materials fit to learning objectives; include activities, assignments and assessment.

\section{Methodology}

This study was designed by using qualitative research methodology. Qualitative research was applied in order to get the confirm-able information of the natural setting situation of the English grammar teachers' attitude towards the use of authentic materials in teaching grammar for English as Foreign Language (EFL) students.

\section{Participants}

There were six teachers of English Education Study Program of Universitas Negeri Gorontalo (UNG) participated in this study. Considering that the aim of this study was to find out the teachers' perspective on the use of authentic materials in teaching grammar, the researchers asked all the teachers who teach English grammar to be the participants in this study. All the teachers who were asked to be the participants agreed to participate.

\section{Data Collection}

The data of this research were collected through questionnaire. The questionnaire was adopted from Akbari, O., and Razavi, A (2015) (was also used by Soliman E. M. Soliman, Malaysia, 2013) with some modification. The questionnaire was selected and customized for the purpose of this study. The questionnaire was distributed to the participants. There were seven questions in the questionnaire with open-response items that guided the participants to describe their experience of teaching grammar using authentic materials to EFL students. The participants were asked to response the given questions according to their opinion and experience in teaching grammar for EFL students. In addition, they were also asked to give comments and suggestion about the use of authentic materials for English grammar teaching. After responding the questioner, the participants gave back the questioner within the given due date. Then the data were analyzed by using qualitative analysis.

\section{Data Analysis}

The collected data were analyzed through three steps. The first step was reading critically; after the data were collected, the researchers critically read the information which the participants gave through the questionnaire to gain a deep understanding about the situation. The second step was interpreting; in this step, the researchers determined the collected data to get the findings regarding to the problem statement of this study, namely what are the teachers' perception on the using of authentic materials in EFL classes? The last step was drawing a conclusion; after reading critically and interpreting the collected data, the researchers then presented the result of the study related to the teachers' perspective on the use of authentic materials in 
teaching grammar for EFL students.

\section{Finding and Discussion}

The bottom line of this study is discussing the teachers' response to the items of questionnaire. It will carry out the purpose of this study, namely: to investigate the teachers' perception in using authentic materials in teaching grammar for EFL students. The substance of the teachers' answer to interview is described through the following points.

\section{Teachers' Preference in Using Authentic Materials.}

The first item of the questionnaire is aimed to have an information whether or not the teachers use authentic materials when they teach grammar subject. The early response after handing the questionnaire and reading the title of this study, they asked the researchers about what the authentic materials are. It shows that they do not have any idea about the term of authentic material. However, after giving a brief explanation of the authentic materials, they eventually understand and realize that they use authentic materials in their grammar class. In other words, they unconsciously use the authentic materials in teaching and learning process, particularly grammar subject.

Responding the first question of the questionnaire, that is would you prefer to use authentic materials in your class in teaching grammar?, all the teachers answered yes, they prefer to use an authentic materials in their grammar subject. They provided some reasons as the answer to the next question of the questionnaire. The teachers choose to use authentic materials in teaching grammar because it gives a different atmosphere to the grammar learning as it can enhance students understanding towards the topic, as well as avoids students' boringness in learning grammar. Furthermore, they said that authentic materials are also interesting and motivating for students to learn grammar because authentic materials are directly contact with their own experience and activities in relation to the real language use. The same point is stated by Scrivener (1996), who said that authentic materials can motivate reluctant learners into overcoming their shyness or fears with regard to language-learning. Moreover, authentic materials make possible for language learners to absorb the reallife example of language used by its native and in turn they will produce the same or approximately near native use of the language. Walkin (1976: 76) in Guariento and Morley (2001: 347) stated that exposure will help them to acquire an effective competence and to bridge the gap between the classroom knowledge and their participation in the real world.

\section{Sources of Authentic Materials to Teach Grammar.}

As previously stated, authentic materials are printed, video, and audio materials students encounter in their daily lives, such as change-of-address forms, job applications, menus, voice mail messages, radio programs, and videos (Ianiro: 2007). According to Ianiro (2007), there are two main categories of authentic materials, 
printed and auditory. Some examples of printed materials are greeting cards, calendars, report cards, TV guides, food labels, magazines, and newspapers. Besides, examples of auditory materials are Phone messages radio broadcasts, movies, videos and DVDs, television programs, and songs.

Due to the question about the authentic materials used to teach grammar, most of the teachers said that they used various sources, such as audio, video, newspaper, magazines and mostly taken from the internet. Internet is taken because it is interactive, up-to-date, provide interesting materials that can stimulate the students' motivation to learn. One of the teachers wrote "For grammar class, I usually used printed materials, not a grammar book, but materials used by everyone in their daily activities like newspaper, books, articles, movies, music recording to give my students samples of the language with which they try to understand the structure".

\section{Criteria of the Selection Materials.}

There are some criteria that the teacher should pay attention to in selecting an appropriate materials, particularly authentic materials, in teaching grammar. According to Berardo (2006), there are three criteria of it. They are suitability of content, exploitability, and readability. Suitability of content associates with students' needs and interest, as well as the compatibility between materials and course objective. Exploitability deals with the idea whether the selection material fits to teaching purpose, in this case teaching grammar.
Additionally, exploitability also refers to the consideration of the usage of the materials to teach grammar. The other criterion is readability. It represents some points about the appropriateness of materials and students' ability. It is regarding to the easiness and difficulty of the vocabulary used in selected authentic materials. What is more, readability discusses if the materials make the students want to read more about the topic.

Concerning to the criteria of the selection materials, the teachers responded that they selected the materials under some conditions. The first is students' needs and interests. The second is the level of students, whether they are in intermediate or advanced level. The third is course objective. The fourth is language level, both vocabulary and grammar level. And the last is the richness of the material. As the response to the item of the questionnaire which asked about the criteria of selection materials, one of the teachers wrote "I look at the course objectives first and decide what materials should be suitable with them. Because from that point, I will be able to assess my students fairly and objectively."

\section{The Role of Authentic Materials in Teaching Grammar.}

Teaching and learning grammar in Indonesian EFL context tend to lead students to memorize the grammatical pattern. Most of text books used for teaching and learning grammar is ask students to do the exercises. For the example ask students to do repetition drills or questions and answer drills. As a result, it 
is difficult for students to understand and use grammar for either written or communicative purposes in real communication.

Some motive mentioned by all participants for bringing authentic materials into the EFL classroom was the benefits that authentic materials offer for their students. All the participants agreed that authentic materials tend to be motivating and interesting for the students as well as more up-to-date and recent than the textbook It also helps students to prepare for the 'real' communication as it provide students with more natural input and language that has not been modified, it guides students towards the language the language they need for particular context and build students interests and motivation in the class.

In grammar class all participants' teachers usually bring in materials that they take from newspaper, book stories or video which they assign students to analyze the structure of particular form of grammar. For example the use of passive voice in all text or they ask students to do mini research finding examples of passive voice in any source especially the authentic ones. Or they prepare a short text taken from online English article and ask students to choose and classify the words on text based on the part of speech.

In teaching grammar to EFL students it is suggested that teachers should not only depend on themselves on their knowledge of introducing sample of language use, but they should involve using aids either visual or audio in class. Though it needs creativity and a lot of work, but the result will be more meaningful for the students.

\section{Conclusion}

This study discovers the teachers' perspective of using authentic materials in EFL classroom. The result revealed that all teachers tend to use authentic materials in teaching grammar to give the opportunity to the students to expose to the real use of language. Furthermore, the result indicated that the teachers use various source of authentic materials such as audio, video, newspaper and magazine. Authentic materials should be chosen in agreement with the criteria of suitability of content, exploitability and readability. Also the teachers should think about students' needs and interests, the level of students, course objective, language level, and the richness of the material. To use authentic materials in classroom activities, particularly grammar subject, teachers are demanded to be more creative to design a classroom activities that suitable with the students' level and needs, as well as the course objectives.

\section{References}

Al Azri, R.H, Al-Rashdi, M.H (2014). The Effect of Using of Authentic Materials in Teaching. International Journal of scientific \& technology, 18, 249-254. Retrieved from http://www.ijstr.org/final-print/oct2014/TheEffect-Of-Using-Authentic-Materials-In-Teaching.pdf 
Berardo, S.A (2006). The Use of Authentic Materials in the teaching of Reading. The Reading Matrix 6.2: 60-69. Retrieved from http://www.readingmatrix.com/articles/berardo/article.pdf

Daskalos, K, Ling, J.J (2005) Authentic Text or Adapted Text- That is the Question.

Retrieved

from http://dspace.mah.se/bitstream/handle/2043/1964/authenticandadapted.pdf

Kilickaya, F (2004) Authentic Materials and Cultural Context in EFL Classroom. The internet TESL Journal. Retrieved from http://iteslj.org/Techniques/Kilickaya-AutenticMaterial.html

Ianiro, Sally (2007). Authentic Materials. Retrieved from http://www.calproonline.org/documents/AuthenticMaterialsFinal.pdf

Morley, J. and W. Guariento. Text and Task Authenticity in the EFL Classroom. ELT journal Vo.55/4. Page. 347-353.

Nunan, D (1999).Second Language Teaching and Learning, Boston, Heinle \& Heinle

Omid, A., Azam, R. (2015). Using Authentic Materials in the Foreign Language Classroom: Teachers' Perspective in EFL Classes. International Journal of Research Studies in Education, (pp. 105-114). Doi: 10.5861/ijrse.2015.1189.

Peacock, A (1997). The Effect of Authentic Materials on the Motivation of ELT Learners, ELT Journal, Oxford, Oxford University Press

Sarapli, O (2011). The use of Authentic Matrials in the Second Language Classroom: Advantages \& Disadvantages, Retieved from http://dergiler.ankara.edu.tr/dergiler/27/1832/19277.pdf

Scrivener, J. (1996) "ARC: A Descriptive Model For Classroom Work On language".In: Willis, J. And Willis, D. (eds.) Challenge And Change In Language Teaching (Oxford: Macmillan Education. Pp. 79-92)

Seeger, I. (2008) Teaching Grammar with Authentic Material. Advantages \& Disadvantages of Deductive and Conciusness-Raising Approach. TESL Modul. Retrieved from http:/www.birmingham.ac.uk/Documents/collegeartslaw/cels/essays/languageteaching/ISeeger-LTM-

Teachinggrammarwithauthenticmaterial-

Advantagesanddisadvantagesofadeductiveandaconsciousnessraisingapproach.pdf

Speller, M. (2002). From Lesson to Life: Authentic Materials Bridge the Gap, ESL Magazine, 5/2, 16-19

Richard, J.C. (2001). Curriculum development in language teaching. Cambridge: Cambridge University Press. 